\title{
Childhood Langerhans Cell Histiocytosis without Risk Organ Involvement
}

National Cancer Institute

\section{Source}

National Cancer Institute. Childhood Langerhans Cell Histiocytosis without Risk Organ

Involvement. NCl Thesaurus. Code C123396.

Langerhans cell histiocytosis that occurs during childhood and does not involve the bone marrow, spleen, liver, or lung. 